\title{
A Case with Cholinergic Poisoning Finding
}

\author{
Ali Karakuş ${ }^{1 *}$, Ezgi Atalay ${ }^{2}$, Güven Kuvandık ${ }^{1}$ \\ ${ }^{I}$ Mustafa Kemal University Faculty of Medicine, Deparment of Emergency Medicine, Hatay-Turkey \\ ${ }^{2}$ Mustafa Kemal University, Hatay Vocational School Of Health Services, First and Emergency Asistance \\ Program, Hatay-Turkey
}

*Corresponding Author: Doctor Ali KARAKUS, Associate Professor Mustafa Kemal University, Faculty of Medicine, Department of Emergency Medicine, Hatay, Turkey, Email: drkarakus@yahoo.com

\begin{abstract}
The sources of organophosphate poisoning are suicide attempts, pesticide and chemical warfare agents. Organophosphates cause acetylcholine (ACh) accumulation in cholinergic receptors so Organophosphate compounds are very toxic.
\end{abstract}

Keywords: Cholinergic intoxication, Organophosphates, War

\section{INTRODUCTION}

Excess acetylcholine results in muscarinic, nicotinic and central nervous system (CNS) effects. Organophosphate intoxication's strong indications are tear, salivation, urination , miosis, nausea-vomiting, pulmonary secretion and muscle weakness.

\section{CASE}

25-year-old male patient was presented to the Emergency Department (ED) with suspicion of poisoning by 112 emergency ambulance services. We learned that the patient came from the battlefield. Primary assessment was made because the patient came from the battlefield. The vital signs of him were not normal. He was unconscious and her glasgow coma scale (GCS) was 3. Eye examination was detected abnormality (pinpoint pupils). The patient had no spontaneous breathing. Endotracheal intubation had been applied. He connected to Mechanical ventilator. On admission his vital signs were temperature $36,3^{\circ} \mathrm{C}$, blood pressure $90 / 60 \mathrm{mmHg}$, pulse rate $84 / \mathrm{min}$, and pulse oximetry reading of $94 \%$. The patient has extensive secretions in the mouth and intubation tube. Arterial blood gas analysis parameters were: $\mathrm{pH}, 7,193$; $\mathrm{HCO} 3$ std, $16.3 \mathrm{mmol} / \mathrm{L} ; \mathrm{pO} 2$ $41,1 \mathrm{mmHg}$; pCO2, $49.5 \mathrm{mmHg}$. Laboratory tests were: WBC 16,99 10^3/uL (3,91 - 10,9); HCT: \%45,8 (\% 40 - 49,4); Glucose: 265,89 $\mathrm{mg} / \mathrm{dL}(70-105)$. Cholinesterase test was: 500 $\mathrm{u} / \mathrm{L}$. Tomography scan (CT) of the brain of him were normal. Patient was administered intravenous push of Atropine 10mg, infusion of
Atropine 10mg, intravenous of Midazolam $5 \mathrm{mg}$ and Rocuronium Bromür $50 \mathrm{mg}$. The patient was cardiac arrest after 8 hour and cardiopulmonary resuscitation (CPR) was started. Despite supportive treatment, the patient who developed cardiac arrest did not respond to resuscitation and was ex.

\section{DISCUSSION}

Organophosphate pesticides are the acetylcholinesterase enzyme (AChE) inhibits. It directly affects the nervous system of the person. They vitalize vital functions.Acetylcholinesterase (AChE) enzyme; It is an enzyme that disables Acetylcholine (ACh), which stimulates nerve cells.Thus, Acetylcholine $(\mathrm{ACh})$ cannot be destroyed and accumulates excessively.Severe twitches can be seen in the muscles resulting in excessive acetylcholine increase. Exposure routes of the nerve agent are breathing, skin and eye contact, swallowing. Also, the nerve agent vapor is more intense than air, which is a negative condition for odor detection. Symptoms for exposed people; vomiting and diarrhea, respiratory distress, pulmonary edema, convulsions, ventricular enlargement and loss of consciousness are the main causes of blurred vision, blurred vision, nasal discharge, dizziness, agitation, excessive secretion production (1-3).

Toxic effects of nerve agents similar to toxic effects of organophosphate pesticides. This compilation will be handled the fatal Sarin Gas for the masses. The toxicity mechanism of sarin 
gas, ways of exposure, clinical findings and emergency medical help will be evaluated in the literature (4).

As medical treatment and antidote; Atropine can prevent excessive nerve stimulation by cutting the acetylcholine receptors. Oximes are used to reactivate the inhibited enzymes so that $\mathrm{ACh}$ can be reduced in excess. Diezapam can be used to control agitation and convulsions.

\section{Conclusion}

Toxic effects of organophosphate pesticides be similar to toxic effects of nerve agents. But, chemical weapons have different destructive effects. Clinical experience in poisonings composed with organophosphate compounds are very much.

\section{REFERENCES}

[1] Alp H, Karakuş A, Çelik MM, Başarslan SK. A Novel Therapeutic Strategy for Organophosphate Poisoning: Phytotherapy Medical Journal of Mustafa Kemal University. 2012; 3: 8-16.

[2] Karakuş A,Çelik MM, Karcioğlu M, Tuzcu K, Erden ES, Zeren C. Cases of organophosphate poisoning treated with high-dose of atropine in intensive care unit and the novel treatment approaches. Toxicology and Industrial Health 2014; 30(5):421-425

[3] Karakuş A, Kuvandık G . Death due to organophosphate poisoning. Causa Pedia 2017; 6(2): 153-154

[4] Kuvandık G, Karakuş A, Fansa I. Poisoning with nerve gas. Editor: Ali Karakuş. Gas poisoing. Derman Medical Publishing, Ankara, 2015.

Citation: Ali Karakus,, Ezgi Atalay, Güven Kuvandik. A Case with Cholinergic Poisoning Finding. ARC Journal of Anesthesiology. 2017;2(3):1-2. doi: dx.doi.org/10.20431/2455-9792.0203001.

Copyright: () 2017 Authors. This is an open-access article distributed under the terms of the Creative Commons Attribution License, which permits unrestricted use, distribution, and reproduction in any medium, provided the original author and source are credited. 